\title{
Comparative evaluation of lateral flow immunoassays, LAMP, and quantitative PCR for diagnosis of fire blight in apple orchards
}

\author{
Jugpreet Singh ${ }^{1} \cdot$ Della Cobb-Smith ${ }^{1} \cdot$ Elizabeth Higgins ${ }^{2} \cdot$ Awais Khan $^{1}$ (D)
}

Received: 11 March 2020 / Accepted: 26 August 2020/Published online: 31 August 2020

(C) Società Italiana di Patologia Vegetale (S.I.Pa.V.) 2020

\begin{abstract}
Fire blight remains a serious threat to commercial apple production in the USA and worldwide. Other diseases and spray damage can result in fire blight-like symptoms that can lead to misdiagnosis and affect disease management strategies. Accurate and timely detection of the fire blight pathogen, Erwinia amylovora, is extremely important to deploy appropriate and timely measures to reduce fire blight epidemics in commercial apple orchards. We tested two commercial lateral flow immunoassays (AgriStrip ${ }^{\circledR}$, and Pocket Diagnostics kit), Loop mediated isothermal amplification (LAMP), and quantitative PCR (qPCR) to diagnose $E$. amylovora infected samples in lab and field settings. The AgriStrip ${ }^{\circledR}$ and Pocket Diagnostics kits were able to detect actively growing bacteria up to $\times 10^{6} \mathrm{cfu} / \mathrm{ml}$ bacterial concentration. Pocket Diagnostics kit had less specificity and showed positive tests for E. pyrifolia in addition to E. amylovora. The LAMP assay showed high specificity for E. amylovora and was able to detect up to $\times 10^{3} \mathrm{cfu} / \mathrm{ml}$ bacterial concentrations. The qPCR assay was also able to detect bacterial cells up to $\times 10^{-3} \mathrm{cfu} /$ $\mathrm{ml}$ bacterial concentration with highly specific $E$. amylovora detection. Grower surveys and comparative cost-benefit analysis indicated that immunoassay kits are less expensive, easier to use, and require less technical expertise for on-site fire blight diagnosis than LAMP and qPCR. However, the choice of a specific diagnostic assay depends on the time, sensitivity, and specificity required for the detection of fire blight and its management.
\end{abstract}

Keywords Pathogen detection $\cdot$ Pathogen diagnosis · Loop mediated isothermal amplification $\cdot$ Enzyme-linked Immuno sorbent assay $\cdot$ Immunoassay $\cdot$ Erwinia amylovora

\section{Introduction}

Fire blight-causing bacteria, Erwinia amylovora, poses a great threat for commercial apple production worldwide (van der Zwet et al. 2012; Norelli et al. 2003). Fire blight has caused significant losses in United States alone, with over \$42 million in Michigan in 2000 (Longstroth 2001) and $\$ 68$ million in northern Oregon and Washington

Electronic supplementary material The online version of this article (https://doi.org/10.1007/s42161-020-00644-w) contains supplementary material, which is available to authorized users.

Awais Khan

awais.khan@cornell.edu

1 Plant Pathology and Plant-Microbe Biology Section, Cornell University, Geneva, NY 14456, USA

2 Eastern NY Commercial Horticulture Program, Cornell Cooperative Extension at Hudson Valley Research Lab, Highland, NY 12528, USA
(Stockwell et al. 2002). The bacteria enter the plants through natural openings or wounds in flowers, leaves, shoots, fruits, and rootstocks (Norelli et al. 2003; Vanneste 2000; Beer et al. 1996). As a result, the bacteria form brownish necrotic lesions on infected tissues, cankers on perennial parts, and a typical shepherd's crook of the terminal branches (van der Zwet et al. 2012; Thomson 2000; Biggs 1994). Severe infection also causes bacterial ooze on the infected tissue surface (Malnoy et al. 2012). These symptoms appear on almost all infected plant parts including leaves, twigs, branches, fruit spurs, blossoms, and rootstocks (Norelli et al. 2003; van der Zwet and Beer 1995). Despite these particular symptoms of fire blight disease, they can still be confused with other symptoms from fungal diseases, abiotic stresses, and spray damage. For instance, early season nectria twig blight and spray damage show similar symptoms of dried out leaves and twigs. Also, water sprouts and fire blight infected plant suckers can appear as spray damage, and a misdiagnosis can lead to rootstock blight and death of a tree. 
E. amylovora can survive both on the surface and inside the tissues of infected plants (Thomson 2000). Hence, the presence of residual inoculum even in asymptomatic plants can become a source of infection and spread. From outside surfaces, fire blight can spread to adjacent trees and orchards through rain, wind, hail damage, and insects. In contrast, an internal migration of bacterial cells from infected blossoms and shoots downwards can lead to rootstock infection (Momol et al. 1998). Under these circumstances, dormant infected wood from nurseries, contaminated budwood, and material transfer between growers can contribute to spread of fire blight across orchards and regions. Thus, any wrong diagnosis mistaken for other pathogens can lead to no management of fire blight in the orchards, which as a result can cause quick accumulation and inoculum spread in a growing season. Pathogen diagnostic laboratories and specialized research labs can provide accurate diagnostics of fire blight through isolating and culturing the bacteria from symptomatic samples, although this could be time consuming due to sample transportation, isolation, culturing and testing. On-site diagnosis of fire blight can provide a quick and appropriate measure to avoid delays associated with remote diagnosis.

Several methods have been used previously to detect the fire blight pathogen from infected samples. Conventional diagnostics have been based on growing and identifying the morphology of bacterial colonies of $E$. amylovora (Kaluzna et al. 2013; Kritzman et al. 2003). For instance, plating and colony assessment of five E. amylovora strains on SNA (Sucrose Nutrient Agar) and King's medium B led to its specific and repeatable detection (Kaluzna et al. 2013). However, screening of colony morphology is labor intensive and requires skilled personnel in well-equipped laboratories to perform the diagnosis. A target-based protein-binding antibody test can provide a more precise and on-site detection of pathogens from symptomatic tissues (Charlermroj et al. 2013; Braun-Kiewnick et al. 2011; Kokoskova and Janse 2009; Thornton 2009). Enzyme-linked immuno sorbent assays and lateral flow immunoassays have been demonstrated to specifically detect $E$. amylovora pathogen up to detection limit of $5.7 \mathrm{cfu} / \mathrm{ml}$ in the symptomatic tissues (Braun-Kiewnick et al. 2011; Kokoskova and Janse 2009). Immunoassay kits are now commercially available that can facilitate an on-site and easy fire blight diagnosis in growers' orchards. The most recent molecular diagnosis approaches use DNA-based amplification (Gaganidze et al. 2018; Kaluzna et al. 2013; Pirc et al. 2009) and engineered bacteriophages (Born et al. 2017) to rapidly detect $E$. amylovora. For instance, standard and real time PCR methods use specific primers, along with various fluorescent dyes, to amplify targeted regions on the E. amylovora genome (Gaganidze et al. 2018; Kaluzna et al. 2013; Pirc et al. 2009). Similarly, the Loop Mediated Isothermal Amplification (LAMP) represents an alternate DNA-based pathogen detection method that relies on the specific dyes, loop primers and isothermal polymerase enzyme to amplify and detect target pathogens within an hour (Shin et al. 2018; Notomi et al. 2015; Kubota and Jenkins 2015; Buhlmann et al. 2013; Kaluzna et al. 2013; Tomlinson 2013; Moradi et al. 2012; Temple and Johnson 2011). Newer LAMP assays can use a battery powered operating system to implement the assay in the orchard (Shin et al. 2018; Buhlmann et al. 2013). Similarly, specific engineering of a Y2 bacteriophage has been reported to detect and control low amounts of viable E. amylovora in a sample (Born et al. 2017). These molecular diagnostic methods can increase the efficiency and specificity of bacterial detection in the infected samples, but still require bacterial culturing and DNA extraction, which need technical expertise to conduct. These modern diagnostic methods can facilitate the initial detection and monitoring of fire blight infection, and resolve uncertainties of fire blight infection from nectria twig blight and spray damage symptoms. Some of these methods have been implemented for pathogen diagnosis in tomato, pepper, citrus, grapes, pear, and apples (Larrea-Sarmiento et al. 2018; Shin et al. 2018; Kong et al. 2016; Keremane et al. 2015; Kaluzna et al. 2013; Buhlmann et al. 2013; Kubota et al. 2008), but their adoption for accurate and on-site fire blight detection in apple still require optimization for sensitivity, precision, time and cost effectiveness.

In this study, we evaluated the efficiency and effectiveness of two immunoassay kits (AgriStrip and Pocket Diagnostics) and a battery-operated device (BioRanger) for LAMP-based on-site detection of E. amylovora strains. These kits were evaluated using bacteria from plating and colony assessment, DNA extraction from the bacteria, and by directly using symptomatic plant tissues. We also used lab-based quantitative PCR (qPCR) to compare the sensitivity and accuracy of detection of various E. amylovora concentrations compared to these different methods. Furthermore, we conducted grower surveys and cost-benefit analysis of various diagnostic methods to assess their feasibility and ease of implementation for fire blight diagnosis in growers' orchards.

\section{Materials and methods}

\section{Plant material and Erwinia strains}

Highly susceptible 'Gala' scions were grafted on 'M.9' rootstocks to perform artificial fire blight inoculation and to harvest samples for diagnosis. The 'M.9' rootstocks were obtained from Willamette Nursery, Canby, OR. The plants were potted into D40H deepots ${ }^{\mathrm{TM}}$ (Stueve and Sons Tangent, OR) containing Sunshine soil mix (Sungrow Horticulture Agawam, MA), and were grown at the Cornell AgriTech greenhouse facilities in Geneva, NY. The greenhouse conditions were maintained at $21-24{ }^{\circ} \mathrm{C}$ temperature with up to $12 \mathrm{~h}$ 
supplemental light. Plants were fertilized once per week with Peters Excel 15-5-15 (ICL Fertilizers, OH) at 200-250 N PPM, and were watered regularly as needed.

We tested strains from seven different Erwinia species that included Erwinia amylovora, Erwinia carotovora betavaculorum, Erwinia mallotivora, Erwinia trachaephila, Erwinia chrysanthemi, Erwinia pyrifolia, and Erwinia lupinicola. In addition, the following specific E. amylovora strains were tested; E2002A (Ea265), E4001A (Ea266), Ea273, Ea235, Ea267, Ea570, Ea572, Ea533, and Ea624a. These strains originate from different host plants and geographical regions (Singh and Khan 2019). We also received fire blight-infected leaf and twig samples from apple growers in New York state.

\section{Preparation of bacterial cultures}

The bacterial cultures were grown either from fire blight infected branches or from previously stored strains as glycerol stocks at $-80 \mathrm{C}$. For bacterial isolation and culture from infected branches, approximately $2.5 \mathrm{~cm}$ of stem tissue surrounding the visual symptoms of fire blight was used. Material was surface sterilized with $70 \%$ ethanol for $1 \mathrm{~min}$, and treated afterwards with $10 \%$ Clorox bleach for $10 \mathrm{~min}$. The sterilized samples were rinsed three times with water, and their bark was skimmed off to expose the cambium layer. Thin $(0.1 \mathrm{~cm}$ thickness $\times 0.5 \mathrm{~cm}$ length) layers of cambium were taken from the healthy-infected transition zone and were plated onto the King's B medium (King et al. 1954). The media plates were incubated at $24-26{ }^{\circ} \mathrm{C}$ for 2 days to grow the bacterial colonies. The resulting bacteria were either directly suspended in water or kit buffer for fire blight infection experiments, or were used for quick DNA extraction to perform various fire blight assays. The bacterial isolation and culturing were done under sterile conditions in the laminar flow hood.

\section{Plant infection assay}

Young plants were inoculated with different E. amylovora strains, once shoot length of the majority $(90 \%)$ of the plants was above $15 \mathrm{~cm}$. Inoculum was prepared with a concentration of $10^{9}$ as described earlier (Silva et al. 2019; Khan et al. 2006). Scissors were dipped in the inoculum and used to cut the youngest leaf (1-2 cm size) for inoculation at approximately the start of the broadest part of the leaf. The entire infected branch (infected and healthy tissue) of each plant was harvested and brought to the lab for bacterial detection in the tissue using different kits. The plant materials sent by growers were collected into plastic bags with a damp paper towel and refrigerated overnight before testing.

\section{Quick bacterial DNA extraction}

We further isolated bacterial DNA for comparisons against the direct bacterial suspensions for fire blight diagnosis. For bacterial DNA extraction, a toothpick full of bacteria was placed into $2 \mathrm{ml}$ locking centrifuge tubes containing $500 \mu \mathrm{l}$ of water. The bacterial suspension was boiled for $10 \mathrm{~min}$, and centrifuged at $12,000 \mathrm{rpm}$ for $10 \mathrm{~min}$. The supernatant was collected into a new centrifuge tube and stored at $4{ }^{\circ} \mathrm{C}$ until further use. The concentration and quality of the extracted DNA was determined using Nanodrop one Spectrophotometer (Thermo Scientific Waltham, MA).

\section{Lateral flow immunoassay kits}

Fire blight diagnosis was performed with two commercial immunoassay kits, AgriStrip kit (Bioreba, Reinach, Switzerland) (Supporting Fig. S1) and Pocket Diagnostics kits (Abingdon Health, York, UK) (Supporting Fig. S2) using fire blight infected samples (material from greenhouse infected plants from 2018), and bacterial suspensions. In addition, the initial bacterial suspensions were quantified with Smart Spec plus spectrophotometer (BioRad, Hercules, CA), and serial dilutions of $\times 10^{7}, \times 10^{6} \times 10^{5}, \times 10^{4}, \times 10^{3}, \times 10^{2}, \times 10^{1} \mathrm{cfu} / \mathrm{ml}$ were generated. The diagnostic kit buffer was used for making serial bacterial dilutions. The AgriStrip Kit contained extraction buffer and immunoassay strips (Supporting Fig. S1). In addition, plastic bags, cuvettes, hammer, pipettes/droppers, toothpicks and knives (not provided by the kits) were purchased separately. The assay was conducted by taking the samples from the transition zone between healthy looking and symptomatic tissue $(0.5 \mathrm{~g}, \sim 2-4 \mathrm{~cm})$. The sample was ground in $4 \mathrm{ml}$ of extraction buffer $\mathrm{C}$ solution in the test bag, and macerated with a hammer to expose pathogen proteins. About $150 \mu \mathrm{l}$ of the pathogen protein containing buffer was transferred into a cuvette. The strip was immersed in it for $15 \mathrm{~min}$ to detect the presence of E. amylovora pathogen. Care was taken to keep the liquid sample below the green area on the AgriStrip. The Pocket Diagnostic kit contained extraction buffer B, metal beads, a dropper, and immunoassay strips (Supporting Fig. S2). For this assay, the test sample $(0.5 \mathrm{~g})$ was cut into less than $0.25 \mathrm{~cm}$ pieces and placed in the bottle of extraction buffer B ( $4 \mathrm{ml})$ containing beads for the extraction of pathogen proteins. The bottle was shaken for $1 \mathrm{~min}$. Two to three drops of the resulting liquid were put onto the strip using a dropper, and any flooding on the Pocket Diagnostic strip was avoided. Deionized water was used as the negative control in each experiment. If both a test line (red in AgriStrip and blue in Pocket Diagnostic) and control line were observed, the sample was declared fire blight positive. The sample was considered fire blight negative if only the control line was visible after using the sample buffer extract. Test was considered invalid and was repeated with no visible 
lines. The immunoassay experiments were conducted using two biological replicates.

\section{Loop mediated isothermal amplification (LAMP)}

A handheld battery-powered portable device called 'BioRanger' (Diagenetix, Inc., Honolulu, HI) was used to perform LAMP assay (Supporting Fig. S3). This device was connected to an Android tablet through Bluetooth. The tablet had BioRanger app installed to start and monitor the site-specific amplification of fire blight pathogen genome and fluorescent detection. The 'BioRanger' device facilitated simultaneous run of eight different reactions at once.

For LAMP assay, fresh infected plant material, bacterial DNA, and serial bacterial dilutions as described above, were used for diagnosis. Bacterial ooze was also used from greenhouse infected material by diluting into $25 \mu \mathrm{l}$ of water. For sample preparation from infected tissues, the cambium layer was exposed and a sterile pipet tip was rubbed three times across the surface at the transition zone. The pipet tips were dipped into a $200 \mu \mathrm{l}$ microfuge tube containing $25 \mu \mathrm{l}$ of sterile water and the process was repeated three times. The resulting samples were lysed in the BioRanger at $95^{\circ} \mathrm{C}$ for $5-10 \mathrm{~min}$ and samples were immediately cooled on ice. These samples served as DNA template for the LAMP reactions from live plant material. In addition, the quick DNA was extracted by boiling and centrifuging the samples as described earlier. The LAMP reaction mixture included: Isothermal enzyme mix (15 $\mu \mathrm{l}$ OptiGene), LAMP and E. amylovora specific primers (Shin et al. 2018), and 1-5 $\mu$ l bacterial DNA from quick extraction (at $50 \mathrm{ng} / \mu \mathrm{l}$ concentration), serial dilutions of bacteria $\left(\times 10^{7}, \times 10^{5}, \times 10^{3}, \times 10^{1}, \times 10^{-1}, \times 10^{-3}\right)$ or lysed bacterial solution from live plant material (unknown concentration). The LAMP primer set (specified as DS-LAMP) comprised a set of five primers as described in Shin et al. (2018); F3 (ATAATAAGAGAATGGCGCTATG), B3 (TCTACATC TCCACCTTTGG), FIP (TAATGAAGTTGAATCTCAGG CATGAGAAAAAATCCATTGTAAAACCTTCG, BIP (GATGGATTGCTTAGTGAGCTCAGCCAATCTCT CCACAACCG), and LoopF (AAAGTTGTTTTCAT CCCACGGA).

Negative control samples were prepared using sterile deionized water. The PCR tubes containing reaction mixture and samples were loaded into the 'BioRanger' device and the reaction temperature was set to $65^{\circ} \mathrm{C}$ for $30-60 \mathrm{~min}$ followed by $80^{\circ} \mathrm{C}$ denaturation for $5 \mathrm{~min}$. Real-time product amplification was monitored and graphically visualized on the tablet. The LAMP experiments were conducted to optimize the reactions for minimum DNA and reagent amounts, and reaction times for high sensitivity. The commercial OptiGene ISO-001 (OptiGene Ltd., Camberley, UK) reaction mixture was used for LAMP reactions, and the assays were performed using three biological replicates.

\section{Quantitative PCR (qPCR) assay}

Bacterial cultures were used to perform the qPCR assay with three biological replicates. The initial bacterial culture concentrations were tested using the Smart Spec plus spectrophotometer (BioRad Hercules, CA), and serial dilutions were made as follows: $\times 10^{7}, \times 10^{5}, \times 10^{3}, \times 10^{1}, \times 10^{-1}, \times 10^{-3}$. The qPCR primers were designed to amplify $60-70 \mathrm{bps}$ around a previously identified single nucleotide polymorphic site in the strains used in this study (Singh and Khan 2019). The primer sequences are: forward (TAAATTGCCATCGCTGGTTGG) and reverse (CGACCGCCAGACGAAAAAT). The reaction mixture consisted of $10 \mu \mathrm{l}$ of Itaq universal SYBR green super mix (BioRad Hercules, CA), $2 \mu$ DNA Template, $1 \mu$ l primer mix $(1 \mu \mathrm{M})$, and $7 \mu \mathrm{l}$ water. The $20 \mu \mathrm{l}$ PCR reaction was conducted with following conditions: denaturation for $5 \mathrm{~min}$ at $95^{\circ} \mathrm{C}$, reaction $65^{\circ} \mathrm{C} 30 \mathrm{~s}$, denature $80{ }^{\circ} \mathrm{C} 5 \mathrm{~s}$, melt 96 to $80{ }^{\circ} \mathrm{C} 0.1 / \mathrm{min}$.

\section{Cost estimates and grower priorities for fire blight detection}

A cost-benefit analysis for the diagnostic assays was performed to compare them with two alternatives for fire blight diagnosis; (1) visual diagnosis in the field or (2) culture and diagnosis in a disease diagnostic laboratory. For lab assays, the cost per sample for standard diagnosis was directly obtained from the website of Plant Disease Diagnostic Clinic at Cornell University (http://plantclinic.cornell.edu/fees.html). The cost of individual strips was calculated from the total pricing of the AgriStrip kit for 100 strips, and from Pocket Diagnostics for the 4 strips included in a single kit. For LAMP and $\mathrm{qPCR}$, the cost was determined from the amount of individual components/reagents used to perform the assay. In addition, the costs of shipping samples to diagnostic labs and for obtaining kits from commercial companies were also added to the final cost for each assay.

To better refine our questions to growers and learn about their current methods of fire blight diagnosis in orchards, an interview was first conducted with an apple grower in the Hudson Valley, NY and two regional tree fruit extension specialists in May, 2019. To confirm the accuracy and time needed for a grower to receive results from a detection assay from the Tree Fruit Pathology lab at Cornell AgriTech, we sent a putative fire blight-infected sample to this laboratory for diagnosis. In addition, we interviewed a scientist working in Tree Fruit Pathology lab at Cornell AgriTech to confirm the costs and timing of lab testing, and to learn about the frequency of visual misdiagnosis in fire blight samples.

In the summer of 2019, 158 commercial apple growers (125 at the Lake Ontario Fruit Tour in June, 2019 and 33 at the Young Fruit Growers Tour in Highland, NY in July 2019), were asked as a group about their current practices in fire 
blight identification in the orchards. The growers were asked whether they have used visual diagnosis or have requested a lab diagnosis of fire blight. The use of the LAMP and two lateral-flow immunoassay kits was also demonstrated during the two grower meetings. In addition, the growers were provided with an opportunity to try the lateral flow immunoassay kits at the meeting and provide feedback. The kits were also provided to 15 growers in Western NY and 12 growers in Highland NY, to try at their farm in order to assess their utility for fire blight diagnosis over current practices. Finally, three additional tree fruit Cornell Cooperative extension specialists, and three tree fruit researchers at Cornell University were interviewed about the benefits of lab vs visual identification for fire blight and their feedback on the grower responses was recorded to identify the representative standards of the industry.

\section{Results}

\section{Immunoassay kits for Erwinia amylovora detection}

The immunoassay tests kits for E. amylovora detection were able to detect $E$. amylovora from the infected tissues in two independent runs (Fig. 1). A very small amount of ooze captured by a toothpick touch (Fig. 1a) was enough to detect the presence of bacteria as indicated by the appearance of test lines in the two immunoassay kit strips (Fig. 1b). The transition zone tissue from infected to healthy parts was also ideal for the fire blight detection. For bark tissues, skimming bark off using a knife to sample the cambium layer was useful for fire blight diagnosis with immunoassay kits (Table 1).

The Pocket Diagnostic kit was able to detect a minimum of $10^{6} \mathrm{cfu} / \mathrm{ml}$ in the bacterial suspension, while AgriStrip was able to detect up to $10^{7} \mathrm{cfu} / \mathrm{ml}$ (Table 2). Bacterial suspensions of E. amylovora strains E2002A and Ea273 showed detection in both the kits (Fig. 2; Table 2). However, Pocket Diagnostics also showed a detection for Erwinia pyrifolia (Fig. 2; Table 2). All other species, including Erwinia carotovora

Table 1 Detection of Erwinia amylovora with the Pocket Diagnostics and AgriStrip immunoassay kits from the infected tissue by skimming off bark tissue in two biological and two technical replications. Here Sample 1 and Sample 2 are biological replicates, and ' $a$ ' and ' $b$ ' represent technical replicates. Note: Detection and no detection is indicated by + and - respectively

\begin{tabular}{lll}
\hline & Pocket Diagnostic & AgriStrip \\
\hline Sample 1a & + & + \\
Sample 1b & + & + \\
Sample 2a & + & + \\
Sample 2b & + & + \\
\hline
\end{tabular}

betavaculorum, Erwinia mallotivora, Erwinia trachaephila, Erwinia chrysanthemi, and Erwinia lupinicola tested negative in both kits (Table 2). The Indicator test lines were relatively easier to read on the Pocket Diagnostic than AgriStrip. Overall, both the immunoassay kits had almost similar sensitivity for detection, whereas Pocket Diagnostic kit had less specificity to detect only E. amylovora.

\section{LAMP-based detection of fire blight}

We used the E. amylovora specific primers from Shin et al. 2018 to perform the LAMP reactions. The LAMP reaction was optimized for the BioRanger device by using bacterial ooze and young twigs. Direct use of bacterial suspension for LAMP required a pre-lysis at $95{ }^{\circ} \mathrm{C}$ for $5 \mathrm{~min}$ in the BioRanger device.

The amplification patterns of LAMP reactions were highly dependent on the bacterial concentration in the solution (Fig. 3). For instance, LAMP assays showed amplification around $\times 10^{-1} \mathrm{cfu} / \mathrm{ml}$ from the bacterial suspension templates (Fig. 3), but the relative fluorescence curves were irregular below $\times 10^{3} \mathrm{cfu} / \mathrm{ml}$ concentration. The efficiency of the LAMP assay was further improved by using the bacterial DNA as a template, since we were able to detect the minimum $\times 10^{-2} \mathrm{cfu} / \mathrm{ml}$ serial dilution of DNA from E2002A strain. However, the latter approach will require isolation or regrowing of isolated bacteria from the infected samples and DNA extraction from them.

Use of ooze and bark rubs from E. amylovora-infected plants also showed E. amylovora detection, as indicated by the fluorescence curves from BioRanger (Fig. 4). We further noted that if samples from bacterial ooze were discolored, or direct use of asymptomatic stem and leaves, did not cause a reaction. In contrast, rubbing the infected bark to obtain bacterial suspensions provided successful amplification of E. amylovora DNA and fire blight diagnosis (Fig. 4).

\section{Quantitative real-time PCR (qPCR) for lab-based E. amylovora detection}

We further used the qPCR approach for E. amylovora specific primers to compare its efficiency with immunoassay kits and LAMP assays. The analysis was conducted using different concentrations of E. amylovora DNA isolated from the in vitro bacterial cultures (Fig. 5). The mean Cycle Threshold $(\mathrm{Ct})$ values were 40.7 in the positive controls, while two replications of negative control samples did not show any relative fluorescence (Fig. 5A; Supporting File S1). The relative fluorescence curves for bacterial DNA amplification sufficiently reflected the differences in the sample concentrations. For example, the average $\mathrm{Ct}$-values changed almost 2-fold from 22.0 to 


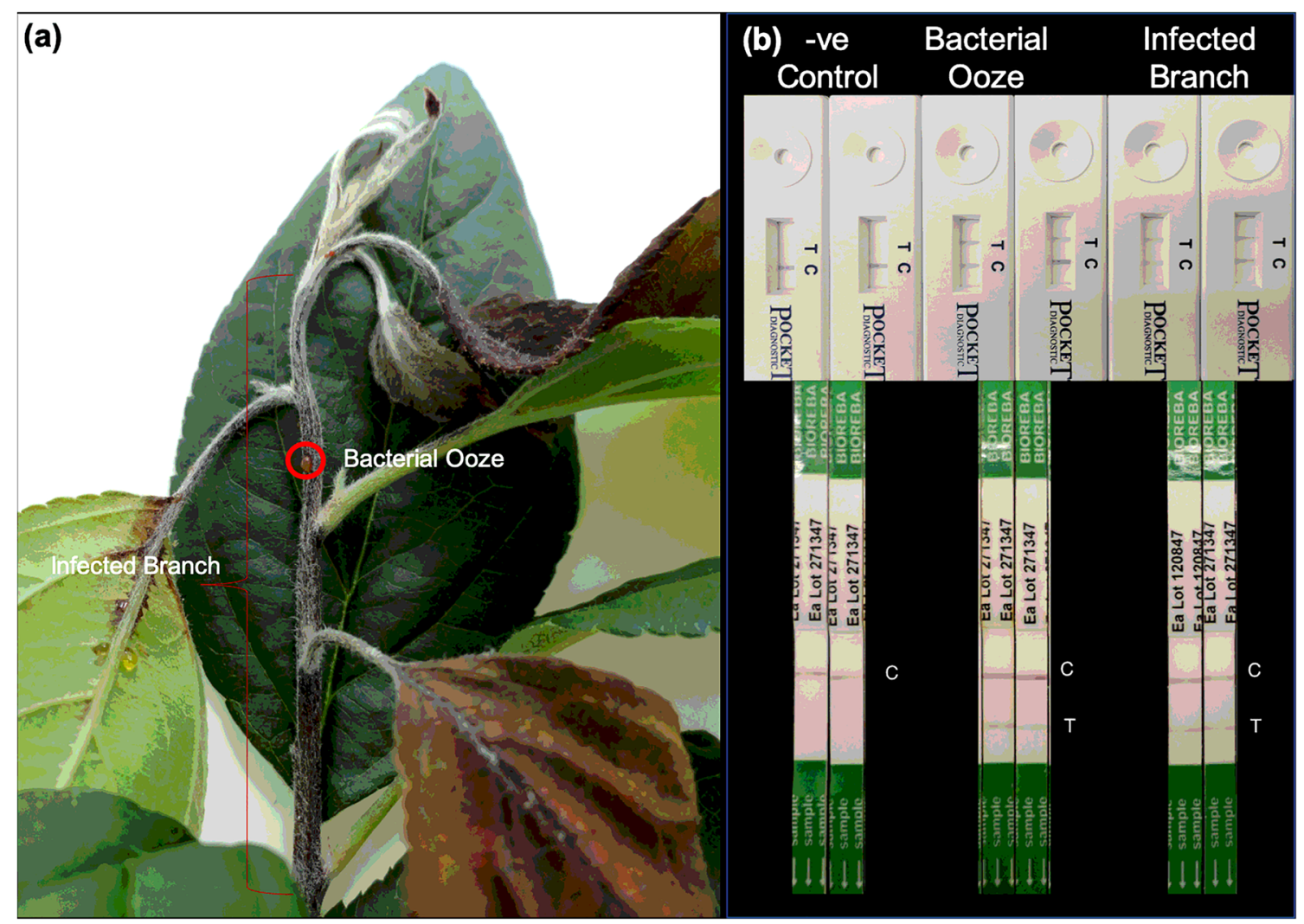

Fig. 1 (a) Fresh fire blight infected samples and (b) Diagnosis of Erwinia amylovora with the Pocket Diagnostics (Top) and AgriStrip (Bottom) immunoassay kits from infected samples and bacterial ooze. The letter

43.6 as the bacterial concentration decreased from $x$ $10^{7} \mathrm{cfu} / \mathrm{ml}$ to $\times 10^{-3} \mathrm{cfu} / \mathrm{ml}$ (Supporting File S1). The bacterial dilutions $\times 10^{5} \mathrm{cfu} / \mathrm{ml}$ and $\times 10^{3} \mathrm{cfu} / \mathrm{ml}$ showed almost similar mean Ct-values equal to approximately 32 . Similarly, the mean Ct-values of approximately 36 were observed for $\times 10^{1} \mathrm{cfu} / \mathrm{ml}$ and $\times 10^{-1} \mathrm{cfu} / \mathrm{ml}$ (Supporting File S1). These low distinctions between the closely defined bacterial dilutions probably happened due to experimental errors. However, we observed a consistent increase in mean $\mathrm{Ct}$-values from $\times 10^{7} \mathrm{cfu} / \mathrm{ml}(\mathrm{Ct}=22.0)$,
'C' on strips indicate the control sample line (buffer without bacteria), and ' $\mathrm{T}$ ' indicate the test sample line. The fire blight positive samples are identified by the visibility of test line ' $\mathrm{T}$ ' on a strip

$\times 10^{3} \mathrm{cfu} / \mathrm{ml}(\mathrm{Ct}=32.1), \times 10^{-1} \mathrm{cfu} / \mathrm{ml}(35.9)$, and $\times$ $10^{-3} \mathrm{cfu} / \mathrm{ml}$ (43.6) (Fig. 5A; Supporting File S1), indicating that qPCR can sufficiently distinguished the concentration differences between these bacterial dilutions. Melting analysis showed single melting curves for each amplified curve (Fig. 5B), hence indicating that amplification curves were specific to E. amylovora. Furthermore, a comparison of qPCR results with immunoassay kits and LAMP revealed its higher efficiency to detect up to serial dilution concentration of $\times 10^{-3} \mathrm{cfu} / \mathrm{ml}$ (Fig. 5).
Table 2 Detection of different dilutions of Erwinia amylovora bacterial suspensions and different Erwinia species with the Pocket Diagnostics and AgriStrip immunoassay kits. Here $\mathrm{Ea}=$ Erwinia amylovora, $\mathrm{Ep}=$ Erwinia pyrifolia, $\mathrm{Ecb}=$ Erwinia carotovora, Ech $=$ Erwinia chrysanthemi. Note: Detection and no detection is indicated by + and - respectively

\begin{tabular}{lll}
\hline Erwinia Species & Pocket Diagnostic & AgriStrip \\
\hline Minimum Conc. Detection (CFU) & $10^{6}$ & $10^{7}$ \\
Erwinia amylovora (Ea273) & + & + \\
Erwinia amylovora (E2002A) & + & + \\
Erwinia pyrifolia (Ep1-96/DSM12162') & + & - \\
Erwinia pyrifolia $($ Ep81-95/DSM12393) & + & - \\
Erwinia carotovora betavaculorum (Ecb107) & - & - \\
Erwinia mallotivora $($ Em5705) & - & - \\
Erwinia trachaephila (Et-cuke1) & - & - \\
Erwinia chrysanthemi (Ec151) & - & - \\
Erwinia lupinicola & - &
\end{tabular}


Fig. 2 Diagnosis of various Erwinia species using the Pocket Diagnostics (Top) and AgriStrip (Bottom) immunoassays. Here $\mathrm{Ea}=$ Erwinia amylovora, $\mathrm{Ep}=$ Erwinia pyrifolia, $\mathrm{Ecb}=$ Erwinia carotovora, Ech = Erwinia chrysanthemi. The letter ' $\mathrm{C}$ ' on strips indicate the control sample line (buffer without bacteria), and ' $T$ ' indicate the test sample line. The fire blight positive samples are identified by the visibility of test line ' $\mathrm{T}$ ' on a strip. The arrows near the Agristrip indicate the position of detected bands

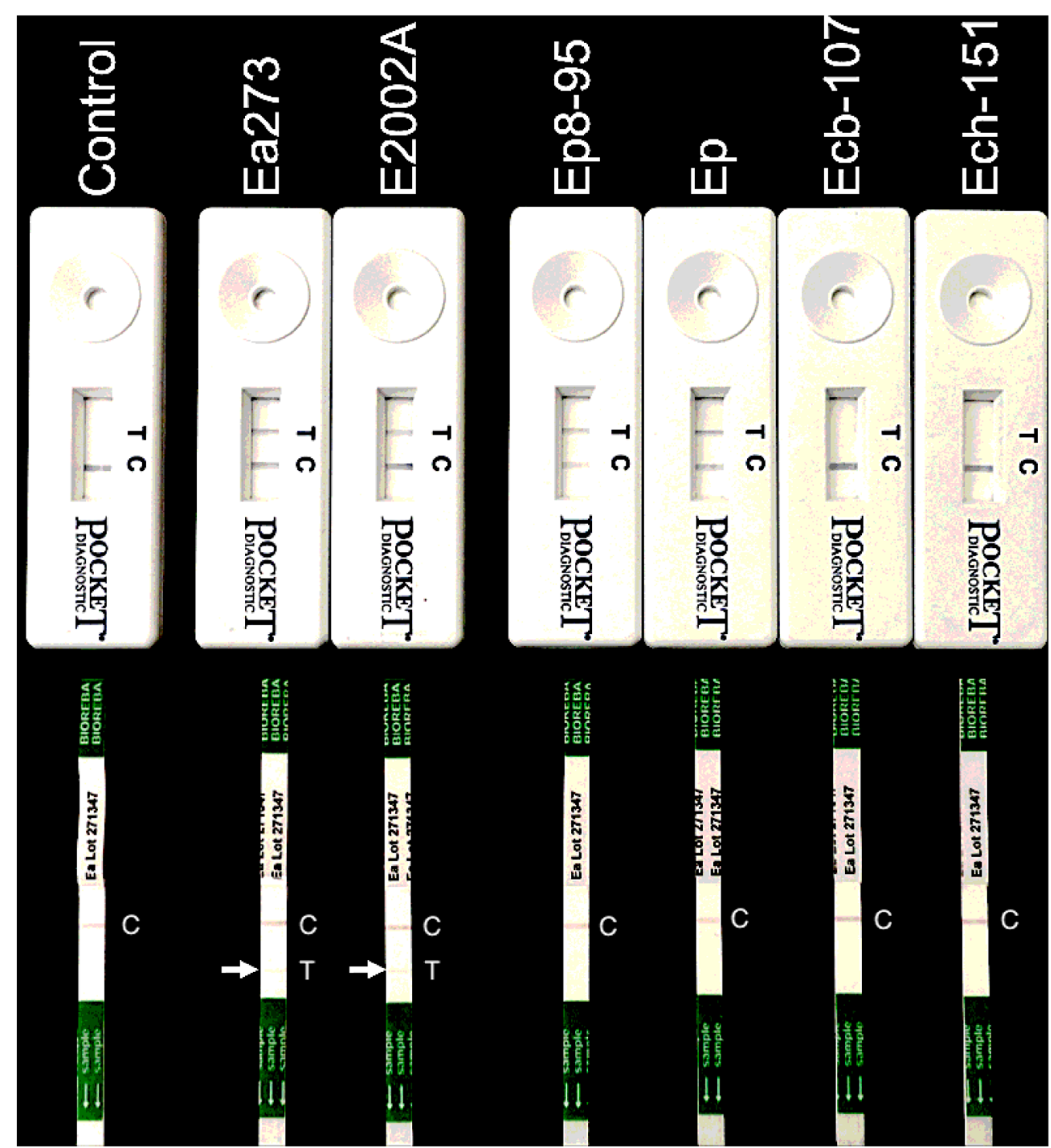

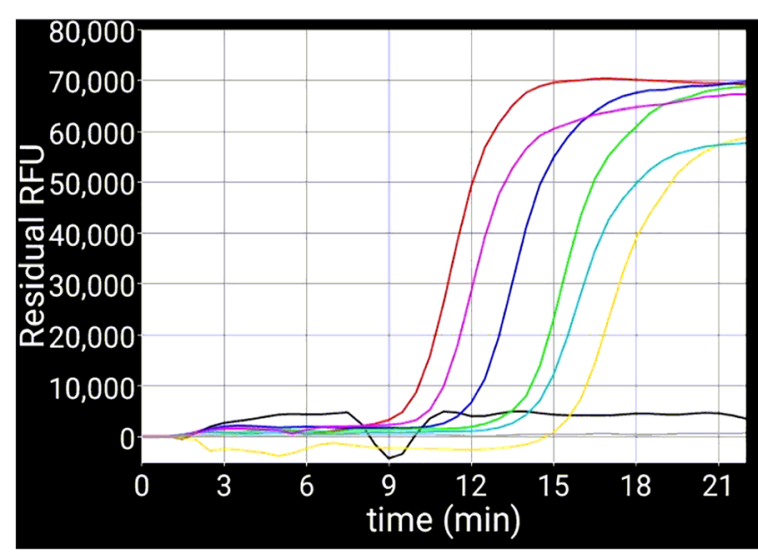

Fig. 3 The fluorescence (A) and melt (B) curves showing amplification of serial dilutions from Erwinia amylovora strain 'Ea273' using Loop mediated isothermal PCR (LAMP). The color of each fluorescence/melt curve represents as black= negative control (optigene mix, water,

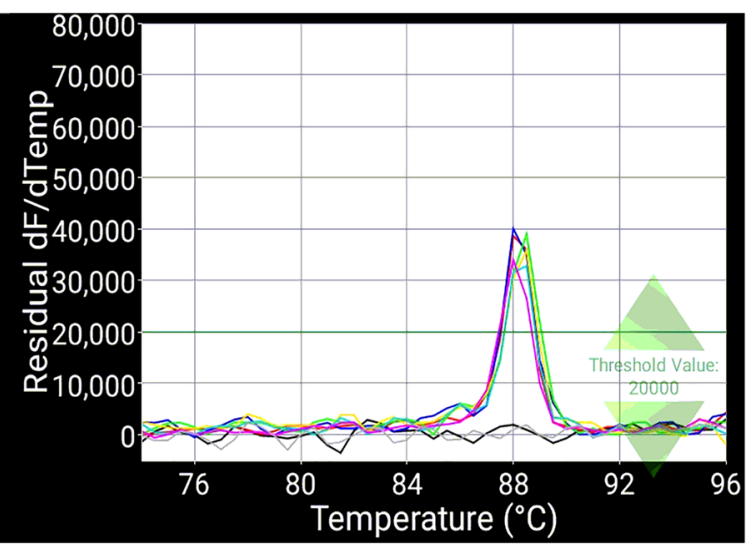

primers), grey $=$ negative control (optigene mix, water, primers), Pink = positive control (optigene mix, water, primers, Ea273 DNA), Red $=\times$ $10^{7} \mathrm{cfu} / \mathrm{ml}$, Blue $=\times 10^{5} \mathrm{cfu} / \mathrm{ml}$, Green $=\times 10^{3} \mathrm{cfu} / \mathrm{ml}$, Yellow $=\times$ $10^{1} \mathrm{cfu} / \mathrm{ml}$, Light blue $=\times 10^{-1} \mathrm{cfu} / \mathrm{ml}$ 


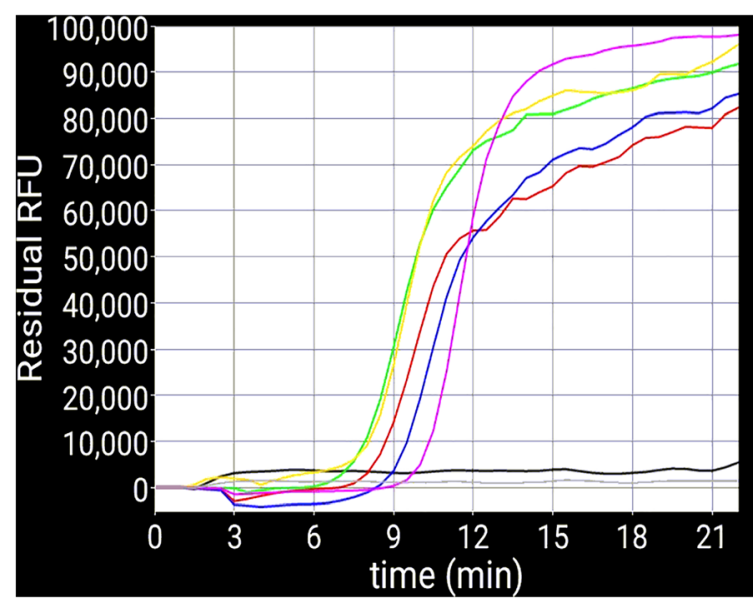

Fig. 4 The fluorescence (A) and melt (B) curves showing amplification of bacterial ooze and bark samples from Erwinia amylovora infected plants with Loop mediated isothermal PCR (LAMP). The color of each fluorescence curve represents as black $=$ negative control (optigene mix,

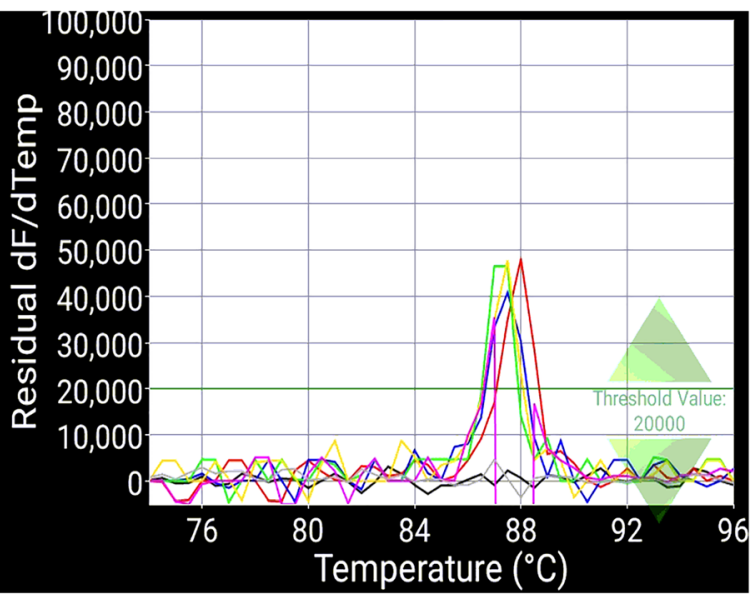

water, primers), grey $=$ negative control (optigene mix, water, primers), pink $=$ positive control (optigene mix, water, primers, Ea273 DNA), red = ooze, blue $=$ bark rub, green $=$ ooze, yellow $=$ bark rub
Fig. 5 Detection of Erwinia amylovora serial dilutions with quantitative PCR (qPCR) in three replications; (A) Fluorescence amplification curves from quantitative PCR runs with different dilutions of bacterial suspensions from Ea273 E. amylovora strain. The $\mathrm{x}$-axis represents number of amplification cycles and y-axis represents the relative

fluorescence unit (RFU), (B)

Melting curves from the qPCR analysis. The $\mathrm{x}$-axis represents the melting temperature and y-axis represent the relative change in RFU per unit temperature. The colors of curves in plots (A) and (B) represent as dark green $=$ negative (primers + SYBR green $+\mathrm{H} 2 \mathrm{O})$, dark red $=$ positive $(\mathrm{Ea} 273 \mathrm{DNA}+$ primers + SYBR green $+\mathrm{H} 2 \mathrm{O}$ ), dark yellow $=\times 10^{7}$ $\mathrm{cfu} / \mathrm{ml}$, light blue $=\times 10^{5} \mathrm{cfu} / \mathrm{ml}$, pink $=\times 10^{3} \mathrm{cfu} / \mathrm{ml}$, light green $=\times 10^{1} \mathrm{cfu} / \mathrm{ml}$, light yellow $=\times 10^{-1} \mathrm{cfu} / \mathrm{ml}$, grey $=\times 10^{-3} \mathrm{cfu} / \mathrm{ml}$

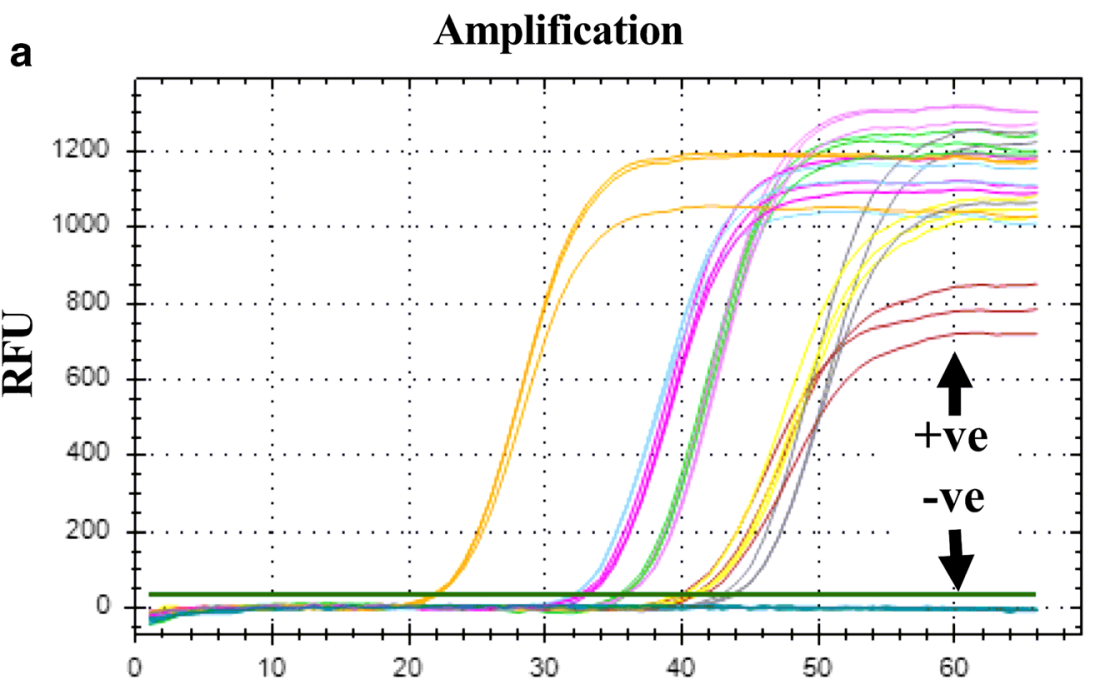

b

Cycles

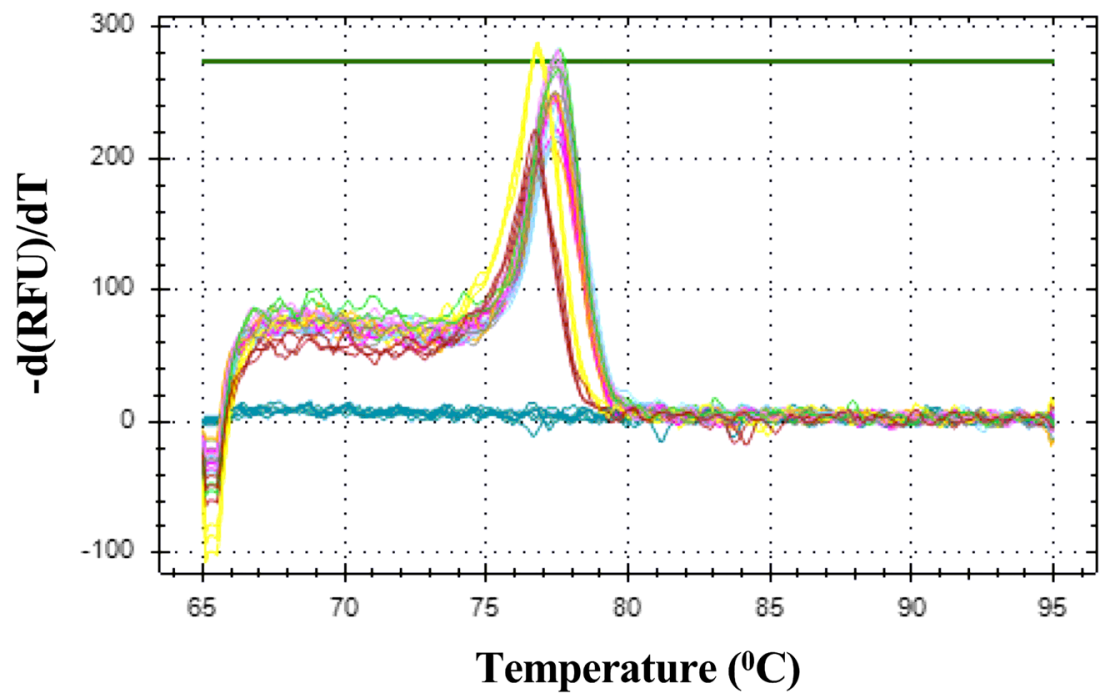




\section{Analysis of cost/benefit for quick fire blight testing}

We have used the cost estimates of testing fire blight samples from the Plant Disease Diagnostic Clinic at Cornell University and two Tree Fruit Pathology research labs at Cornell University and compared it with the rapid fire blight diagnostic methods tested here. The Plant Disease Diagnostic Clinic at Cornell University culture and test fire blight samples from NYS growers at $\$ 35$ per sample, and it takes about a week to provide results after receiving the samples (Table 3; Supporting File S2). Similarly, Tree Fruit Pathology labs at Cornell AgriTech and Hudson Valley Research Lab (HVRL) also culture and test fire blight samples. However, unlike commercial labs, the availability of testing depends on staff availability and funding. These research labs generally do not charge growers for lab testing of fire blight due to support by grants. Given that the staffing, testing techniques and overhead rates are roughly the same, the costs at both diagnostics and research labs were likely the same. In both cases, overnight shipping of samples to a diagnostic lab had additional $\$ 20-30$ associated costs. Fire blight diagnosis tests by these labs are very accurate. The erroneous results tended to come from poor sample selection and handling during shipping.

The two lateral flow immunoassay kits and the BioRanger LAMP assay were considerably less expensive per test (out of pocket) and faster than current lab-based fire blight testing options available to farmers. All three tests provided results within $30 \mathrm{~min}$. The AgriStrip kit currently costs about $\$ 4.25$ a sample, depending on a minimum purchase of 100 samples (Table 1; Supporting File S2). The minimum out of pocket cost was $\$ 425$ for the test strips and materials. The Pocket Diagnostic kit costs about $\$ 8.50$ per sample. The minimum number of kits for purchase was 8 ( 2 boxes of 4 ) to keep the minimum out of pocket cost about $\$ 68$. The BioRanger LAMP assay had an upfront cost of about $\$ 4000$ for the BioRanger, android tablet, and isothermal mixture for 400 reactions. Supplies for the BioRanger were estimated at about $\$ 1.86$ per test. The cost of the BioRanger test matched with the AgriStrip test and Pocket Diagnostic assays after 949 and 474 tests, respectively, without including staff time.

\section{Grower priorities and rapid fire blight detection}

Out of 125 growers at the Western NY tour, only 3 growers had previously sent samples to confirm fire blight symptoms at the remote diagnostic labs. None of the 33 growers at Highland, New York, had ever used lab diagnostic assays to identify fire blight in their orchards. Both groups of growers responded that they had a high confidence in the accuracy of visual detection of fire blight, and they intended to use appropriate treatments after visual symptoms appear that look like fire blight. The length of time between seeing potential fire blight in the orchard and waiting for test results was also mentioned as a barrier to pursue a lab test. Most growers indicated that they preferred to act aggressively after detecting fire blight-like symptoms, rather than risk losses from fire blight.

The samples sent to Cornell Plant Diagnostic Lab to assess the cost and response time for the lab diagnostics did not test positive for fire blight. According to Cornell Plant Diagnostic Lab, a large number of samples that are suspected of being fire blight from visual symptoms by growers and tree fruit extension specialists, did not test positive for fire blight in their fire blight tests. Similarly, interviews with expert professionals, who routinely test fire blight samples for research studies, indicated that a high number of visually identified fire blight infected samples received by their lab from farmers and extension specialists were false positives.

The consensus from LAMP demonstrations indicated its difficulty to use in the field, and a need for experienced personnel to do the test and interpret results. Moreover, the survey pointed out that the BioRanger will only be cost effective to conduct a high volume of tests over several years due to high equipment costs, and when accuracy is important. Infrequent use of BioRanger will be expensive. In contrast, the results from grower demonstrations and take-home usage
Table 3 Upfront and per sample cost and time estimate of different fire blight diagnostic assays. The amplification-based methods are polymerase chain reaction (PCR) and loop-mediated isothermal amplification (LAMP). Immunoassays used are Pocket Diagnostics and AgriStrip

\begin{tabular}{|c|c|c|c|c|}
\hline Diagnostic Methods & Upfront cost & $\begin{array}{l}\text { Cost per } \\
\text { sample }\end{array}$ & Material used & $\begin{array}{l}\text { Time to } \\
\text { results }\end{array}$ \\
\hline Cornell Diagnostic Lab & \$20-30 shipping & $\$ 35$ & $\begin{array}{l}\text { Bacterial } \\
\text { isolation }\end{array}$ & $\sim 7$ days \\
\hline Traditional PCR & $\$ 20,274$ & $\$ 1.75$ & $\begin{array}{l}\text { Bacterial } \\
\text { isolation }\end{array}$ & $\sim 7-10$ days \\
\hline LAMP (dye) & $\$ 3540$ & $\$ 0.82$ & $\begin{array}{l}\text { Bacterial } \\
\text { isolation }\end{array}$ & $\sim 7-10$ days \\
\hline $\begin{array}{l}\text { LAMP BioRanger } \\
\text { (fluorescence) }\end{array}$ & $\begin{array}{l}\$ 4032 \text { (including mix for } 400 \\
\text { reactions) }\end{array}$ & $\$ 1.86$ & Direct sample & $\sim 1 \mathrm{~h}$ \\
\hline AgriStrip & $\$ 425$ (100 samples) & $\$ 4.25$ & Direct sample & $\sim 20 \mathrm{~min}$ \\
\hline Pocket Diagnostics & $\$ 339$ (40 samples) & $\$ 8.50$ & Direct sample & $\sim 20 \mathrm{~min}$ \\
\hline
\end{tabular}


of AgriStrip and Pocket Diagnostic Kits by 27 growers in Western and Highland New York indicated that these kits were easy to use and had potential for on-site fire blight detection. The growers mainly preferred the Pocket Diagnostic kit because of its ease of use and reading results was clearer.

\section{Discussion}

Based on laboratory testing of accuracy and sensitivity, cost-benefit analysis, and survey responses from growers on ease of use, we find the two lateral immunoassay kits were best for wide usage in commercial apple orchards for fire blight diagnosis. These immunoassay kits, AgriStrip and Pocket Diagnostics, were simple to use in the orchards and needed the least technical expertise. The AgriStrip showed high specificity for E. amylovora in this study, but Pocket Diagnostics showed positive tests for E. pyrifolia as well (Table 2). However, the AgriStrip had previously shown positive detection for some strains of E. pyrifoliae and E. piriflorinigrans (Braun-Kiewnick et al. 2011). These findings suggest that the E. amylovora specific antibodies can cross-react to the proteins from different strains in other Erwinia species, leading to their positive detection. In comparison, the sensitivity of immunoassays was lower than the LAMP and qPCR diagnostic methods. The immunoassay antibodies probably need a higher amount of protein from the bacterial samples to bind and show detection signals. In contrast, a very low amount of bacterial DNA could be enough as a template for successful amplification in LAMP and qPCR. We observed amplification curves with $\times 10^{3} \mathrm{cfu} / \mathrm{ml}$ in LAMP and qPCR assays (Fig. 3; Fig. 5). The sensitivity of LAMP and qPCR were identified to be higher than conventional diagnostic methods for Alternaria solani and Phytophthora infestans detection from potato, tomato, and other related host plants (Okiro et al. 2019; Khan et al. 2018; Lees et al. 2019). The real-time PCR has previously also been identified as the most sensitive method, followed by LAMP assay, to detect the Xylella fastidiosa pathogen from blueberry (Waliullah et al. 2019). However, both LAMP and qPCR-based diagnostic methods require technical expertise to perform and interpret the test results, and also require high initial investment costs (Notomi et al. 2015; Tomlinson 2013; Pirc et al. 2009; López et al. 2009; Stöger et al. 2006). Also, the components required to run qPCR and LAMP assay can be hard to implement at field sites. Thus, the use of a particular diagnostic method depends on the necessity for quick and reliable diagnosis of fire blight. Growers can use any of the lateral flow immunoassay kits for a quick cost-effective and more frequent fire blight testing from a large number of samples on-farm (Braun-Kiewnick et al. 2011). The DNA amplification- based methods are not likely to be adopted by individual growers, but on-site LAMP diagnosis will be more useful to the extension educators or crop consultants as a more sensitive solution for pathogen detection. It can also save time and cost to transport samples, and can avoid sample error due to poor handling during transport. However, cost calculations of fire blight assays represent current prices, which can differ in the future as these technologies become more accessible and advanced.

The clearest economic benefit of rapid testing, in the short run, will be preventing the misallocation of economic resources, since the chances of visual diagnosis going wrong are relatively high. The negative test results from lab diagnoses of visually identified fire blight samples by growers and extension specialists confirm the high possibility of mis-diagnosis, suggesting that the ability to diagnose fire blight through visual symptoms is not always accurate. Moreover, diseases like nectria twig blight and European canker, and pest damage from twig borer beetle cause almost similar symptoms as fire blight (van der Zwet and Beer 1995; Roberts et al. 1998) that can lead to mis-diagnosis and false treatments for fire blight like symptoms. In such circumstances, growers either take unnecessary measures to extensively prune nectria, European canker, and beetle damaged branches at the expense of other farm activities (Steiner 2000; Norelli et al. 2003), or avoid pruning fire blight strikes, increasing the inoculum for infection in successive years. The estimated cost of per/acre pruning a mature high-density orchard with 908 trees per acre is about $\$ 250$ /acre or about $\$ 0.30$ per tree (Wells 2015). The pruning costs in-season are not insignificant, and also pruning does not confirm the complete removal of bacteria. Once the bacteria move into rootstock tissues, it can potentially kill the entire tree. Furthermore, plants always remain vulnerable after the pathogen enters inside the tissues that can serve as an inoculum source to cause disease epidemics and leave non-productive orchards for several years, particularly in high density orchards. These planting systems are highly prone to quick fire blight outbreaks due to less spacing between trees, narrow canopy size, and smaller lateral branches. In addition, fruit spurs stay close to the main stem in high density planting system, and any instance of leftover inoculum can easily spread to stem and reproductive tissues. Apple growers use antibiotics and growth regulators to control fire blight infection and spread (van der Zwet et al. 2012; Norelli et al. 2003), which can add to production costs and cause evolution of antibiotic resistance strains (Förster et al. 2015; McManus et al. 2002; Chiou and Jones 1995). Moreover, treatment of fire blight using antibiotic sprays and growth regulators will not be effective against nectria twig blight, and spray damage, hence a mis-diagnosis can lead to overuse of fire blight 
spray treatments that can add unnecessary input costs to the orchard.

Depending on the time to perform management tasks, growers can opt to diagnose on-farm with immunoassay kits or can send samples for highly sensitive PCR-based diagnosis to extension educators, diagnostic labs, or research lab having active fire blight programs. The immunoassays diagnosis took approximately $20 \mathrm{~min}$, and provided results much faster than the lab diagnostics (Table 3). The latter using LAMP, qPCR, and sample submission to diagnostic labs can take minimum $1 \mathrm{~h}$ to several days to provide results (Khan et al. 2018). Hence, the use of any of these methods will depend upon the necessity for rapid and accurate detection of fire blight in the commercial orchards. Recently, it has been shown that remote sensing and hyperspectral imaging can also help in pathogen diagnosis (Lowe et al. 2017; Kuska et al. 2015; Qin et al. 2009) and can facilitate the early detection and monitoring of fire blight in the commercial orchards (Jarolmasjed et al. 2019; Bagheri et al. 2018). For example, RGB and multispectral imaging, and hyperspectral sensing detected potential spectral bands for early fire blight symptoms in apple orchards (Jarolmasjed et al. 2019). The nearinfrared spectroscopy coupled with specific statistical approaches was also able to detect fire blight in nonsymptomatic leaves in pear (Bagheri et al. 2018). These image-based disease detection tools again require special instruments and technical expertise for imaging and data analysis. However, they might resolve the uncertainties between fire blight infection and related symptoms from nectria twig blight and spray damage.

In summary, appropriate diagnostics can facilitate implementation of fire blight control and management measures before significant damage occurs. The use of pathogen detection assays on-site can improve fire blight management and minimize the risk of economic loss, especially considering that apple growers do not routinely request lab tests and mainly rely on imprecise visual diagnosis to identify fire blight infection. Nonetheless, rapid and accurate fire blight diagnosis can ultimately enhance the profitability of orchard operations, and entire value chain involved in apple nursery, production, marketing, retail, and product development business.

Acknowledgements This research was supported by the New York Farm Viability Institute (NYFVI) grant \# FVI 18011 . We acknowledge the help of David Strickland, Rachel Baschieri, Eric Dinglasan and Richard Tegtmeier during optimization and validation of the protocols.

Author contributions A.K. designed the experiment and supervised the research. D.C-S. conducted the laboratory experiments to develop and test the assays. E.H. did the cost estimates and worked together with D.C-S. to perform the survey. J.S. wrote the manuscript with support of D.C-S. and E.H. A.K. and J.S. revised the manuscript. All authors have read and approved the manuscript.

\section{Compliance with ethical standards}

Conflict of interest The authors declare that they have no competing interests.

Declarations Not applicable

\section{References}

Bagheri N, Mohamadi-Monavar H, Azizi A, Ghasemi A (2018) Detection of fire blight disease in pear trees by hyperspectral data. Euro. J. Remote Sens 51:1-10

Beer SV, Kim JH, Zumoff CH, Bogdanove AJ, Laby RJ, Gutafson HL, Momol MT (1996) Characterization of bacteria that cause 'bacterial shoot blight of pear' in Japan. Acta Hortic 411:179e181

Biggs AR (1994) Characteristics of fire blight cankers following shoot inoculations of three apple cultivars. HortScience 29:795-797

Born Y, Fieseler L, Thony V, Leimer N, Duffy B, Loessner MJ (2017) Engineering of bacteriophages $\mathrm{Y} 2:: \mathrm{dpoL} 1-\mathrm{C}$ and $\mathrm{Y} 2:: 1 \mathrm{lu} A \mathrm{~B}$ for efficient control and rapid detection of the fire blight pathogen, Erwinia amylovora. Appl Environ Microbiol 83(12):e00341e00317

Braun-Kiewnick A, Altenbach D, Oberhansli T, Bitterlin W, Duffy B (2011) A rapid lateral-flow immunoassay for phytosanitary detection of Erwinia amylovora and on-site fire blight diagnosis. J. Microbiological Methods 87:1-9

Buhlmann A, Pothier J, Rezzonico F, Smits T, Andreou M, Boonham N, Duffy B, Frey J (2013) Erwinia amylovora loop-mediated isothermal amplification (LAMP) assay for rapid pathogen detection and on-site diagnosis of fire blight. J Microbiol Meth 92:332-339

Charlermroj R, Himananto O, Seepiban C, Kumpoosiri M, Warin N, Oplatowska M, Gajanandana O, Grant IR, Karoonuthaisiri N, Elliott CT (2013) Multiplex detection of plant pathogens using a microsphere immunoassay technology. PLoS One 8:e62344

Chiou CS, Jones AL (1995) Molecular analysis of high-level streptomycin resistance in Erwinia amylovora. Phytopathology 85:324-328

Förster H, McGhee GC, Sundin GW, Adaskaveg JE (2015) Characterization of streptomycin resistance in isolates of Erwinia amylovora in California. Phytopathology 105:1302-1310

Gaganidze DL, Aznarashvili MA, Sadunishvili TA, Abashidze EO, Gureilidze MA, Gvritishvili (2018) Fire blight in Georgia. Annals Agrarian Science 16: 12-16

Jarolmasjed S, Sankaran S, Marzougui A, Kostick S, Si Y, Vargas JJQ, Evans K (2019) High-throughput phenotyping of fire blight disease symptoms using sensing techniques in apple. Front Plant Sci 10:576

Kaluzna M, Pulawska J, Mikicinski A (2013) Evaluation of methods for Erwinia amylovora detection. J Hort Res 21:65-71

Keremane ML, Ramadugu C, Rodriguez E, Kubota R, Shibata S, Hall DG, Roose ML, Jenkins D, Lee RF (2015) A rapid field detection system for citrus huanglongbing associated 'Candidatus Liberibacter asiaticus' from the psyllid vector, Diaphorina citri Kuwayama and its implications in disease management. Crop Prot 68:41-48

Khan M, Wang R, Li B, Liu P, Weng Q, Chen Q (2018) Comparative evaluation of the LAMP assay and PCR-based assays for the rapid detection of Alternaria solani. Front Microbiol 9:2089

Khan MA, Duffy B, Gessler C, Patocchi A (2006) QTL mapping of fire blight resistance in apple. Mol Breed 17:299-306

King EO, Ward MK, Raney DE (1954) Two simple media for the demonstration of pyocyanin and fluorescin. J Lab Clin Med 44:301-307

Kokoskova B, Janse JD (2009) Enzyme-linked immunosorbent assay for the detection and identification of plant pathogenic bacteria (in 
particular for Erwinia amylovora and Clavibacter michiganensis subsp. sepedonicus). Methods Mol Biol. 508:75-87

Kong X, Qin W, Huang X, Kong F, Schoen CD, Feng J, Wang Z, Zhang $H$ (2016) Development and application of loop-mediated isothermal amplification (LAMP) for detection of Plasmopara viticola. Sci Rep 6:28935

Kritzman G, Shwartz H, Marcus R, Manulis S, Klietman F, Oppenheim D, Zilberstaine M, Shtienberg D (2003) Testing a rapid diagnostic medium for Erwinia amylovora and development of a procedure for sampling blossoms in pear orchards. Phytopahtology 93:931-940

Kubota R, Vine BG, Alvarez AM, Jenkins DM (2008) Detection of Ralstonia solanacearum by loop-mediated isothermal amplification. Phytopathology 98:1045-1051

Kubota R, Jenkins DM (2015) Real-time duplex applications of loopmediated amplification (LAMP) by assimilating probes. Int $\mathrm{J}$ Mol Sci 16:4786-4799

Kuska M, Wahabzada M, Leucker M, Dehne H-W, Kersting K, Oerke EC, Steiner U, Mahlein A (2015) Hyperspectral phenotyping on the microscopic scale: towards automated characterization of plantpathogen interactions. Plant Methods 11:28

Larrea-Sarmiento A, Dhakal U, Boluk G, Fatdal L, Alvarez A, StrayerScherer A, Paret M, Jones J, Jenkins D, Arif M (2018) Development of a genome-informed loop-mediated isothermal amplification assay for rapid and specific detection of Xanthomonas euvesicatoria. Sci Rep 8:14298

Lees AK, Roberts DM, Lynott J, Sullivan L, Brierley JL (2019) Real-time PCR and LAMP assays for the detection of spores of Alternaria solani and sporangia of Phytophthora infestans to inform disease risk forecasting. Plant Dis 103:3172-3180

Longstroth M (2001) The 2000 fire blight epidemic in Southwest Michigan apple orchards. Compact Fruit Tree 34:16-19

López MM, Llop P, Olmos A, Marco-Noales E, Cambra M, Bertolini E (2009) Are molecular tools solving the challenges posed by detection of plant pathogenic bacteria and viruses? Curr Issues Mol Biol 11:13-46

Lowe A, Harrison N, French AP (2017) Hyperspectral image analysis techniques for the detection and classification of the early onset of plant disease and stress. Plant Methods 13:80

Malnoy M, Martens S, Norelli JL, Barny M, Sundin GW, Smits THM, Duffy B (2012) Fire blight: applied genomic insights of the pathogen and host. Annu Rev Phytopathol 50:475-494

McManus PS, Stockwell VO, Sundin GW, Jones AL (2002) Antibiotic use in plant agriculture. Annu Rev Phytopathol 40:443-465

Momol MT, Norelli JL, Piccioni DE, Momol EA, Gustafson HL, Cummins JN, Aldwinckle HS (1998) Internal movement of Erwinia amylovora through symptomless apple scion tissues into the rootstock. Plant Dis 70:1017-1019

Moradi A, Nasiri J, Abdollahi H, Almasi M (2012) Development and evaluation of a loop-mediated isothermal amplification assay for detection of Erwinia amylovora based on chromosomal DNA. Euro J Plant Pathol 133:609-620

Norelli JL, Jones AL, Aldwinckle HS (2003) Fire blight management in the twenty-first century: using new technologies that enhance host resistance in apple. Plant Dis 87:756-765

Notomi T, Mori Y, Tomita N, Kanda H (2015) Loop-mediated isothermal amplification (LAMP): principle, features, and future prospects. J Microbiol 53:1-5

Okiro LA, Tancos MA, Nyanjom SG, Smart CD, Parker ML (2019) Comparative evaluation of LAMP, qPCR, conventional PCR, and ELISA to detect ralstonia solanacearum in Kenyan potato fields. Plant Dis 103:959-965

Pirc M, Ravnikar M, Tomlinson J, Dreo T (2009) Improved fire blight diagnostics using quantitative real-time PCR detection of Erwinia amylovora chromosomal DNA. Plant Pathol 58:872-881
Qin J, Burks TF, Ritenour MA, Bonn WG (2009) Detection of citrus canker using hyperspectral reflectance imaging with spectral information divergence. J Food Engineer 93:183-191

Roberts RG, Hale CN, van der Zwet T, Miller CE, Redlin SC (1998) The potential for spread of Erwinia amylovora and fire blight via commercial apple fruit; a critical review and risk assessment. Crop Prot 17:19-28

Shin DS, Heo GI, Son SH, Oh CS, Lee YK, Cha JS (2018) Development of an improved loop-mediated isothermal amplification assay for on-site diagnosis of fire blight in apple and pear. The Plant Pathol J 34:191-198

Silva KJP, Singh J, Bednarek R, Fei Z, Khan A (2019) Differential gene regulatory pathways and co-expression networks associated with fire blight infection in apple (Malus $\times$ domestica). Hort Res 6:35

Singh J, Khan A (2019) Distinct patterns of natural selection determine sub-population structure in the fire blight pathogen, Erwinia amylovora. Sci Rep 9:14017

Steiner PW (2000) Integrated orchard and nursery management for the control of fire blight. In: Vanneste J L, ed., Fire blight: the disease and its causative agent, Erwinia amylovora. CABI, Wallingford. pp. 339-358

Stockwell VO, Johnson KB, Loper JE, Lindow SE, Hecht-Poinar EI, Elliott VJ (2002) Biological control of fire blight: understanding interactions among introduced and indigenous microbial communities. In Phyllosphere microbiology, eds S. E. Lindow, E. I. HechtPoinar, and V. J. Elliot (St. Paul, MN: APS press), 225-239

Stöger A, Schaffer J, Ruppitsch W (2006) A rapid sensitive method for direct detection of Erwinia amylovora in symptomatic and asymptomatic plant tissue by polymerase chain reaction. Plant Pathol 154: 469-473

Temple TN, Johnson KB (2011) Evaluation of loop-mediated isothermal amplification for rapid detection of Erwinia amylovora on pear and apple fruit flowers. Plant Dis 95:423-430

Thomson SV (2000) Epidemiology of fire blight. In J. Vanneste (Ed.), Fire blight, the disease and its causative agent, Erwinia amylovora, CAB International, Wallingford (GB), 2000

Thornton CR (2009) Production of monoclonal antibodies to plant pathogens. Meth Mol Biol 508:63-74

Tomlinson J (2013). In-field diagnostics using loop-mediated isothermal amplification. In methods in molecular biology (Clifton, N.J.). 938. 291-300

van der Zwet T, Beer SV (1995) Fire blight- its nature, prevention and control. In a practical guide to integrated disease management, USDA agricultural information bulletin, vol. 631, USDA, Washington (US), 1995

van der Zwet T, Orolaza-Halbrendt N, Zeller W (2012) Losses due to fire blight and economic importance of the disease. In: fire blight: history, biology, and management. St Paul, MN: APS press/American Phytopathological society

Vanneste JL (2000) What is fire blight? Who is Erwinia amylovora? How to control it? In: Vanneste J (ed) Fire blight. CABI, New York, pp 17

Waliullah S, Hudson O, Oliver JE, Brannen PM, Ji P, Ali ME (2019) Comparative analysis of different molecular and serological methods for detection of Xylella fastidiosa in blueberry. PLoS One 14(9):e0221903

Wells M (2015) Pruning Labor Cost Calculator (Excel Spreadsheet) Cornell Cooperative Extension Lake Ontario Fruit Team. https:// tinyurl.com/t8zfpsj

Publisher's note Springer Nature remains neutral with regard to jurisdictional claims in published maps and institutional affiliations. 